The Israeli Journal of Aquaculture - Bamidgeh, IJA_69.2017.1352, 12 pages

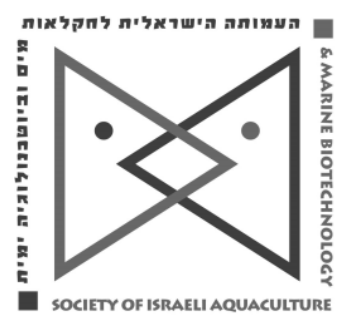

The IJA appears exclusively as a peer-reviewed on-line open-access journal at http://www.siamb.org.il. To read papers free of charge, please register online at registration form.

Sale of IJA papers is strictly forbidden.

\title{
Assessment and Potential Application of the Probiotic Strain, Bacillus amyloliquefaciens JFP2, Isolated from Fermented Seafood-Jeotgal in Flounder Paralichthys olivaceus Juveniles
}

\section{Dong-Hwi Kim ${ }^{1 \dagger}$, Dharaneedharan Subramanian ${ }^{1 \dagger}$, So-Hyun Park ${ }^{1}$, Yeoung-Hwan Jang ${ }^{2}$, Moon-Soo Heo ${ }^{1 *}$}

${ }^{1}$ Marine Applied Microbes and Aquatic Organism Disease Control Lab, Department of Aquatic Biomedical Sciences, School of Marine Biomedical Sciences \& Marine and Environmental Research Institute, Jeju National University, Jeju 63243, Republic of Korea.

${ }^{2}$ Fish Disease Diagnostic Lab, Jeju Special Self-Governing Province Ocean and Fisheries Research Institute, Pyoseon-myeon, Segwipo-si, Jeju 63629, Republic of Korea

Keywords: bacteriocin; jeotgal; Bacillus amyloliquefaciens JFP2; flounder fish culture

\begin{abstract}
The strain Bacillus amyloliquefaciens JFP2 was isolated from Jeotgal, traditional fermented seafood from Jeju Island, South Korea to assess its probiotic and antibacterial effect against fish pathogens. The isolate JFP2 was identified using scanning electron microscopic analysis and 16S rRNA gene sequence analysis. The isolated strain, $B$. amyloliquefaciens JFP2 showed a broad spectrum of antibacterial activity against both Gram-positive and Gramnegative fish pathogenic bacteria namely Aeromonas hydrophila, Edwardsiella tarda, Photobacterium damselase sup-sps, Photobacterium phosphoreum, Streptococcous parauberis, S. iniae and Vibrio anguillaram. The bacteriocin JFP2 with a molecular mass of $37 \mathrm{kDa}$ that was purified by ammonium sulphate precipitation followed by carboxymethyl-Sephadex column chromatography, showed antibacterial activity at a range of temperatures, from $4^{\circ}-45^{\circ} \mathrm{C}$ and at a range of $\mathrm{pH}$ values from 2-12. However, loss of antibacterial activity was observed after treating the bacteriocin with proteolytic enzymes such as pepsin, proteinase $\mathrm{K}$, and trypsin. The mode of antibacterial action shown by the bacteriocin JFP2 was bacteriolytic in nature, resulting in cell wall degradation of $A$. hydrophila. Dietary inclusion of the isolated JFP2 strain showed improved growth performance in juvenile flounder along with increased disease resistance against Streptococcus iniae. These results indicate that the bacteriocin JFP2 belongs to class IIIa bacteriocin that could be used as a potential alternative antibacterial agent to control pathogenic diseases in aquaculture and seafood industries.
\end{abstract}

* Corresponding author. Tel.: place telephone number here (optional), fax: fax number here (optional), e-mail: email address here (required) 


\section{Introduction}

The occurrence and spread of diseases in the aquaculture industry could significantly decrease productivity and encourage fish farmers to use antibiotics extensively as a strategy in disease management. However, for the past two decades, the application of probiotics in the prevention and management of fish diseases has received more interest (Ganguly et al., 2010). Most probiotic microbes are marketed as drug or foodstuffs and safe application has been confirmed through long-term experience (Lim et al., 2005). Increased use of probiotic bacteria as biological controllers is effective and safer than antibiotics (Bansemir et al., 2006). Antibacterial activity in probiotic bacteria may occur by the production of bacteriocins (Avonts and Vuyst, 2001) which are antimicrobial peptides or proteins that kill other related (narrow spectrum) or non-related (broad spectrum) microbiotas as one of the inherent defense mechanism of bacteria (Cotter et al., 2013). The mode of bacteriocin action includes destruction of cell walls, formation of pores in cell membrane, disruption of cell membrane followed by cell lysis and inhibition of nuclease activity (Lim et al., 2011).

Several studies have reported such antimicrobial proteins or bacteriocins, derived mainly from lactic acid bacteria, as safe and effective natural food preservatives (Cleveland et al., 2001). They have been isolated primarily from meat and dairy products, are also nontoxic to humans, and leave no residues (Cotter et al., 2013). Bacteriocins are used as bio-preservatives of vegetable foods and beverages and their application appears to be a possible alternative to chemical compounds and antibiotics (Collins et al. 2010).

Korean traditional fermented seafood, Jeotgal is one of the most important foods in Korea and is fermented by naturally occurring microorganisms (Lee et al., 2014). It is prepared by adding $20-30 \%(\mathrm{w} / \mathrm{w})$ salt to various types of seafood such as shrimp, oyster, shellfish, fish, fish eggs, and intestines, followed by preservation through fermentation (Guan et al., 2011). Several studies have reported the jeotgal fermentation process (Roh, et al., 2010; Choi et al., 2013) which includes Bacillus subtilis, Leuconostoc mesenteroides, Pediococcus halophilus and other salt resistant aerobic and anaerobic bacteria (Lee, 1993). However, the molecular characterization of those bacterial species and their potential application is scarce (Mohammadou et al., 2014). The present study was carried out to isolate and characterize the bacterial strain Bacillus amyloliliquefaciens JFP2 from Jeju Island's traditional fermented seafood jeotgal, and assess its probiotic antimicrobial properties along with its dietary influence on Paralichthys olivaceus growth and disease resistance.

\section{Materials and Methods}

Jeju Island's traditional fermented food. Fully ripened and ready to consume samples of salted, fermented seafood product Jeotgal, were purchased from the local traditional markets on Jeju Island, S. Korea and used for the isolation of bacteria. The $\mathrm{pH}$ of the samples was measured using an Orion 3-star Benchtop $\mathrm{pH}$ meter (Thermo Fisher Scientific, Rockford, Ill., U.S.A.), and the percentage of salt was measured using a Pocket PAL-03S portable refractometer (ATAGO, Japan). Sampling for bacterial isolation was carried out in three replications immediately after collection of the samples.

Isolation and characterization of bacteria. About $10 \mathrm{mg}$ of Jeotgal sample was homogenized and $10^{3}$-fold diluted with a sterile saline solution $(0.85 \%, \mathrm{w} / \mathrm{v})$. The diluted suspension was plated on marine agar (MA; Difco., U.S.A.) supplemented with $1 \%, 2 \%$, $5 \%, 10 \%$, and $15 \%$ of $\mathrm{NaCl}$, and incubated aerobically at $30{ }^{\circ} \mathrm{C}$ for $3-5 \mathrm{~d}$. Clearly isolated colonies were subcultured on MRS agar media (de Man Rogosa and Sharp) (MRSB; Difco., USA), and incubated at $37^{\circ} \mathrm{C}$ for $48 \mathrm{hrs}$. After incubation, the cultures were repropagated twice to insure purity and then stored at $-80^{\circ} \mathrm{C}$ with $20 \%$ sterile glycerol for further use. Strains with good antimicrobial ability were selected for further investigation.

Strain identification was carried out using conventional morphological and biochemical tests as described by Shen et al. (1999). Molecular confirmation of the identified strain was done with $16 \mathrm{~S}$ Rrna gene sequences analysis which includes; 1 ) the genomic DNA of the identified strain JFP2 was isolated; 2) 16S rRNA gene was amplified from chromosomal DNA by PCR using universal oligo-nucleotide primers (16s forward 
primer: 5'- AGAGTTTGATCCTGGCTCAG $-3^{\prime}$ and $16 \mathrm{~s}$ Reverse Primer: 5'GGTTACCTTGTTACGACTT -3'); 3) The amplicon was sequenced and compared with the $16 S$ rRNA sequences in the GenBank database by BLASTN; 4) Multiple sequence alignment was done using CLUSTAL X software and a phylogenetic tree was constructed by the neighbor-joining method using MEGA (Version 4.1) software. The confidence level of each branch (1000 repeats) was tested by bootstrap analysis.

Antibiotic sensitivity and resistance pattern of strain JFP2. Antibiotic resistance and susceptibility of the isolated strain was analyzed by disc diffusion method as recommended by the national committee for clinical laboratory standards (Wayne, 1997). Cells from $48 \mathrm{~h}$ old cultures were diluted in $1: 20 \mathrm{LB}$ broth and $100 \mu \mathrm{l}\left(10^{5} \mathrm{CFU} / \mathrm{ml}\right.$ bacteria) was swabbed on top of the nutrient agar plates and allowed to dry for 10 mins. Various antibiotic impregnated discs (Life Technology, S. Korea) were placed on the surface of the swabbed plates and left for 30 mins at room temperature for the diffusion of the antibiotics. The plates were then incubated for $20 \mathrm{~h}$ at $37^{\circ} \mathrm{C}$, after which the strain JFP2 was classified as sensitive or resistant to an antibiotic based on the zone of growth inhibition (ZI) given in standard antibiotic chart.

Probiotic properties of the strain JFP2

Resistance to acidic gastric conditions and high temperature. To determine the resistance to acidic conditions of stomach, viable cells were counted during incubation for $120 \mathrm{~min}$ at $37^{\circ} \mathrm{C}$ in MRS broth adjusted to $\mathrm{pH} 2.0$ using $0.1 \mathrm{~N} \mathrm{HCl}$. The number of viable cells was determined by plating samples on MRS solid medium and incubating at $37^{\circ} \mathrm{C}$ for $48 \mathrm{~h}$. The resistance of selected strain to bile salts secreted into duodenum was tested by the growth of the strain JFP2 in the presence of bile salt oxgall (Sigma, S. Korea) added to the concentration of $3 \%(\mathrm{w} / \mathrm{v})$ by the method described by Walker and Gilliland (1993). The growth of strain JFP2 was monitored during incubation at $37^{\circ} \mathrm{C}$ statically up to $7 \mathrm{~h}$ by reading at $600 \mathrm{~nm}$ optical density. The isolate was cultured in MRS broth for $24 \mathrm{~h}$ at $37^{\circ} \mathrm{C}$ statically, and then heated to $50^{\circ} \mathrm{C}$ and $60^{\circ} \mathrm{C}$ for $30 \mathrm{~min}$. After heat treatment, viable cells were counted by plating the heated culture on MRS solid medium.

Proteolytic activity. The proteolytic activity was measured by growing JFP2 strain in $10 \%$ skim milk at $37^{\circ} \mathrm{C}$ for $42 \mathrm{~h}$. The absorbance was read at $650 \mathrm{~nm}$ with a spectrophotometer (Libra S22 UV/Visible, Biochrom, England) (Citi et al., 1963). The results were expressed as $\mathrm{mg} / \mathrm{mL}$ tyrosine by means of reference to a calibration curve.

Evaluation of cell surface hydrophobicity. The cell surface hydrophobicity assay was conducted according to the method described by Lee et al. (2011) with slight modifications. Freshly prepared cells were centrifuged at $8000 \mathrm{rpm}$ for $10 \mathrm{~min}$. The cells of the isolated JFP2 strain cultured at $37^{\circ} \mathrm{C}$ in MRS broth were harvested by centrifugation $\left(10000 \times \mathrm{g}, 10 \mathrm{~min}\right.$ at $4^{\circ} \mathrm{C}$ ) at the early growth phase (12 h culture), washed twice with PBS ( $\mathrm{pH} 7.0$ ), resuspended in PBS and the absorbance was measured at $580 \mathrm{~nm}$ (reading 1). One $\mathrm{ml}$ of hydrocarbon (Toluene, hexadecane or Xylene) was added to $3 \mathrm{ml}$ of washed cells, and mixed thoroughly for 2 min using a vortex. The phases were allowed to separate at room temperature for $30 \mathrm{~min}$, after which $1 \mathrm{ml}$ of the upper phase was removed and the absorbance was determined at OD $580 \mathrm{~nm}$ (reading 2). Percentage hydrophobicity was calculated as: (OD $580 \mathrm{~nm}$ of cells (reading 1) - OD 580 $\mathrm{nm}$ of aqueous phase (reading 2)/OD580nm of cells (reading 1 ) $\times 100=\%$ hydrophobicity.

Anitoxidant ability of the strain JFP2. The DPPH radical-scavenging capacity of the strain JFP2 was determined according to the method described by Li et al. with some modifications (2012) where $1.0,1.5,2.0$ and $2.5 \mathrm{ml}$ of freshly prepared JFP2 cells $\left(10^{7}\right.$ $\mathrm{CFU} / \mathrm{ml})$, was added to $1.0 \mathrm{ml}$ methanolic DPPH radical solution $(0.05 \mathrm{mM})$. The mixture was mixed vigorously and incubated at room temperature in the dark for $30 \mathrm{~min}$. The controls included only deionized water and DPPH solution. The blanks contained only methanol and the cells. The absorbance of the resulting solution was measured in triplicate at $517 \mathrm{~nm}$, after centrifugation at $12000 \mathrm{rpm}$ for $10 \mathrm{~min}$.

Antimicrobial properties of the strain JFP2. The isolated JFP2 bacterial strain was tested for the production of antimicrobial substance activity of the cell free culture supernatant (CFCS) using disc diffusion method along with broth micro-dilution assay to determine the minimum inhibitory concentration (MIC) of the JFP2 strain. CFCS was prepared by centrifugation $\left(8000 \times \mathrm{g}, 5\right.$ mins, $4^{\circ} \mathrm{C}$ ) of JFP2 culture grown on MRS broth 
at $37^{\circ} \mathrm{C}$ for $48 \mathrm{~h}$, adjustment to $\mathrm{pH} 7.0$ with $1 \mathrm{~N} \mathrm{NaOH}$ and filter sterilized through 0.45 $\mu \mathrm{m}$ pore Millipore membrane filter.

Antimicrobial assay against fish pathogens. Antibacterial activity of the isolated JFP2 strain was determined against seven major fish pathogens namely Aeromonas hydrophila, Edwardsiella tarda, Photobacterium damselase sup-sps, Photobacterium phosphoreum (Gram negative bacteria) and Streptococcous parauberis, S. iniae, Vibrio anguillarum (Gram positive bacteria) which were isolated from infected flounder collected from fish farms located in and around Jeju island. Fish pathogens were cultured in Brain Heart Infusion (BHI) broth at $37^{\circ} \mathrm{C}$ on a shaking incubator (at $190 \mathrm{rpm}$ ) overnight. For the disc diffusion assay, a lawn of bacterial culture was prepared by spreading $100 \mu \mathrm{L}$ culture broth $\left(10^{7} \mathrm{CFU} / \mathrm{mL}\right)$ of each test organism on solid BHI agar plates. Paper discs impregnated with JFP2 CFCS were air dried and laid on BHI agar plates previously inoculated with pathogens and allowed to stand for 15 mins at $4{ }^{\circ} \mathrm{C}$ aseptically. Later the plates were incubated at $37^{\circ} \mathrm{C}$ for $24 \mathrm{~h}$. For micro-dilution assay, pathogenic bacteria were cultured overnight at $37^{\circ} \mathrm{C}$ in $\mathrm{BHI}$ broth and adjusted to a final density of $10^{7}$ $\mathrm{CFU} / \mathrm{mL}$ by 0.5 McFarland standards. Then, in a 96 -well plate, $90 \mu \mathrm{L}$ of BHI broth was added, and $10 \mu \mathrm{L}$ of CFCS was diluted eight times serially. Thus, $10 \mu \mathrm{L}$ of bacterial culture was inoculated and then the 96 -well plate was incubated at $37^{\circ} \mathrm{C}$ for $12 \mathrm{~h}$ in a shaking incubator rotating at $150 \mathrm{rpm}$. The concentration at which there was no, or minimally observable bacterial growth (as noted by least visible bacterial growth), was taken as the MIC. Tetracycline was used as positive control and test results were scored when a zone of inhibition was observed after the incubation period. Both assays were performed in triplicate and the mean \pm standard error (SE) was calculated.

Column purification and SDS-PAGE separation of antibacterial substance bacteriocin. For bacteriocin production, the isolated strain JFP2 was grown in MRS broth for $24 \mathrm{~h}$ at $37^{\circ} \mathrm{C}$ and CFCS prepared as stated before. The CFCS containing crude bacteriocin was filtered through $0.45-\mu \mathrm{m}$ filter membranes, and proteins were precipitated with ammonium sulphate at $50 \%$ saturation by constant stirring overnight for $16 \mathrm{~h}$ at $4^{\circ} \mathrm{C}$. Initial purification was achieved by $0-50 \%$ ammonium sulfate salting out to the culture supernatant. The precipitated crude extract was harvested by centrifugation at $10,000 \mathrm{~g}$ for $20 \mathrm{~min}$ and dissolved in the $10 \mathrm{mM}$ Tris $-\mathrm{HCl}$ buffer $(\mathrm{pH}$ 8.0). The concentrated solution was loaded on to a column $(1.6 \times 10 \mathrm{~cm})$ of anionexchange diethylaminoethyl (DEAE)-Sepharose Fast Flow (Life Technology, Korea), previously equilibrated with $10 \mathrm{mM}$ Tris- $\mathrm{HCl}$ buffer $(\mathrm{pH} \mathrm{8.0)}$, and the column was eluted with a linear gradient of $0-0.5 \mathrm{M} \mathrm{NaCl}$ in $0.1 \mathrm{M}$ Tris. $\mathrm{HCl}$ buffer $(\mathrm{pH} .8 .0)$ at a flow rate of 1 $\mathrm{mL} / \mathrm{min}$. The active fractions were pooled and applied to a column $(2.6 \times 60 \mathrm{~cm})$ of Sephacryl S-100 HR (Life Technology, Korea), and eluted with $10 \mathrm{mM}$ Tris . HCl buffer $(\mathrm{pH} 8.0)$ at $1 \mathrm{~mL} / \mathrm{min}$. The fractions showing antibacterial activity were pooled and lyophilized to characterize their biochemical properties. Protein concentration was determined by using BCA method with bovine serum albumin as a standard (Sigma, USA) and the molecular weight was determined by SDS-PAGE separation. The purified bacteriocin was detected through $12 \%$ separating and $5 \%$ stacking gel with acrylamide and bis-acrylaminde ratio 30:1 under denaturing condition. $15 \mu \mathrm{l}$ of bacteriocin (5 $\mathrm{mg} / \mathrm{ml}$ ) mixed in $4: 1$ ratio with denaturing sample buffer was loaded per well along with CFCS and blank medium as negative controls in separate wells. Electrophoresis was done at $20 \mathrm{~mA}$ for first 30 mins followed by $30 \mathrm{~mA}$ for $2 \mathrm{~h}$. Then the gel was removed and stained with Coomassie brilliant blue G-250 and de-stained to visualize the separated protein bands.

Antibacterial mechanism of bacteriocin against Aeromonas hydrophila. Late-log phase of Aeromonas hydrophila culture in BHI broth maintained at $37^{\circ} \mathrm{C}$ for $12 \mathrm{~h}$ was used to explore the antibacterial mechanism of partially purified bacteriocin of $B$. amyloliquefaciens JFP2 by cell wall destruction procedure (Borrero et al., 2011). Bacterial cell with viable density of $10^{6} \mathrm{CFU} / \mathrm{mL}$ was pelletized and suspended in $5 \mathrm{~mL}$ of $10 \mathrm{mM}$ sodium phosphate buffer ( $\mathrm{pH} 7.0)$. To this $100 \mu \mathrm{L}$ of bacteriocin was added and allowed to stand for 15 mins at $37^{\circ} \mathrm{C}$ and then centrifuged at $4^{\circ} \mathrm{C}$ for $2000 \mathrm{rpm}$, supernatant was collected and rinsed in $10 \mathrm{~mL}$ of potassium buffer $(p \mathrm{H} 7.0)$. SDS (4\%, w/v) was added and mixed for $90 \mathrm{~min}$ at room temperature. The mixture was treated for $15 \mathrm{~min}$ at $100^{\circ} \mathrm{C}$, and the cell wall was collected by centrifugation at $14,000 \times \mathrm{g}$ for $15 \mathrm{~min}$ at $4^{\circ} \mathrm{C}$. 
The mixture was resuspended in $10 \mathrm{~mL}$ of $0.1 \%$ Triton $\mathrm{X}-100$ (Sigma-Aldrich) and was stirred for $30 \mathrm{~min}$ at room temperature. After centrifugation, the mixture was resuspended in $1 \mathrm{~mL}$ of $5 \mathrm{mM}$ sodium phosphate buffer $(\mathrm{pH} \mathrm{7.0)}$, and the optical density was measured at $600 \mathrm{~nm}$.

Sensitivity of bacteriocin to different $p \mathrm{H}$, temperatures, and enzymes. To study temperature sensitivity of JFP2 bacteriocin, the aliquots of partially purified bacteriocin $(4,000 \mathrm{AU} / \mathrm{mL})$ were exposed to different temperatures: $4,30,45,60$ and $75^{\circ} \mathrm{C}$ for 30 min and residual activity was measured using spot-on-lawn method (Paik and Glatz, 1995) through dilution of bacteriocin against the indicator lawn of bacteria namely Aeromonas hydrophila. The titer was the least dilution showing inhibition zone expressed in antimicrobial activity unit per milliliter $(\mathrm{AU} / \mathrm{mL})$. For stability at different $p \mathrm{H}$, the aliquots were adjusted to range between 2.0-12.0 pH using $2 \mathrm{~N} \mathrm{HCL}$ and $2 \mathrm{~N} \mathrm{NaOH}$, and incubated for 2 hours. The residual activity was measured after neutralizing the aliquots to $\mathrm{pH}$ 6.0. To investigate enzyme sensitivity, partially purified and lyophilized bacteriocin JFP2 (4,000 AU/mL) was treated with degrading enzymes (Sigma, Korea) such as lysozyme $(10,000 \mathrm{AU} / \mathrm{mL})$, a-amylase $(100 \mathrm{AU} / \mathrm{mL})$ and proteinase $\mathrm{K}(200 \mathrm{AU} / \mathrm{mL})$ and incubated at $37^{\circ} \mathrm{C}$ for 2 hours. The untreated purified bacteriocin and saline were used as positive and negative controls respectively. The residual activity was measured as the diameter of inhibition zone $(\mathrm{mm})$.

Dietary effect on olive flounder disease resistance. Isolated $B$. amyloliquefaciensJFP2 culture was suspended in sterile saline water and sprayed over the flounder fish feed (Suhyup, S.Korea) in concentrations of $1.4 \times 10^{4}$ (P1), and $1.4 \times 10^{8}$ (P2) CFU/100 $\mathrm{g}$, excluding control feed (C); stored at $4^{\circ} \mathrm{C}$ until use. About 90 healthy olive flounder $(105 \pm 0.26 \mathrm{~g})$ purchased from a flounder fish farm located in Jeju Island were randomly grouped as Control (C), Probiotic1 (P1), and Probiotic2 (P2), in triplicate $(n=10)$. Fish were fed standard culture practice at $4 \%$ body weight for 30 days. Dietary performance was evaluated through estimation of nutritional indices such as live weight gain (LWG), feed conversion ratio (FCR), specific growth rate (SGR), and disease resistance was assessed by challenge with Streptococcus iniae; survival rate was recorded for 20 days.

Statistical analysis. Data were statistically analyzed using SPSS version 11.0. One way analysis of variance (ANOVA) and Duncan's Multiple Range Test were applied to compare means between treatments.

\section{Results}

Among the hundred and eight different bacterial species isolated from Jeju Island's traditional fermented seafood product, isolate JFP2 was selected for further strain characterization based on its abundant growth in MRS selective medium and its wide spectrum of antimicrobial ability (data not shown). The staining test and scanning electron microscope analysis revealed it to be a Gram-positive bacterium with rodshaped (0.7-0.9 $\mu \mathrm{m}$ thick, 1.5-3.0 $\mu \mathrm{m}$ long) cells. (Fig. 1). Biochemical tests confirmed that the investigated bacterial species was aerobic, testing positive for catalase, nitrate reduction, indole, capable of starch and gelatin hydrolysis, and negative for methyl red and Voges Proskauer assays.

Fig. 1. Scanning electron microscopic image of B. amyloliquefaciens JFP2

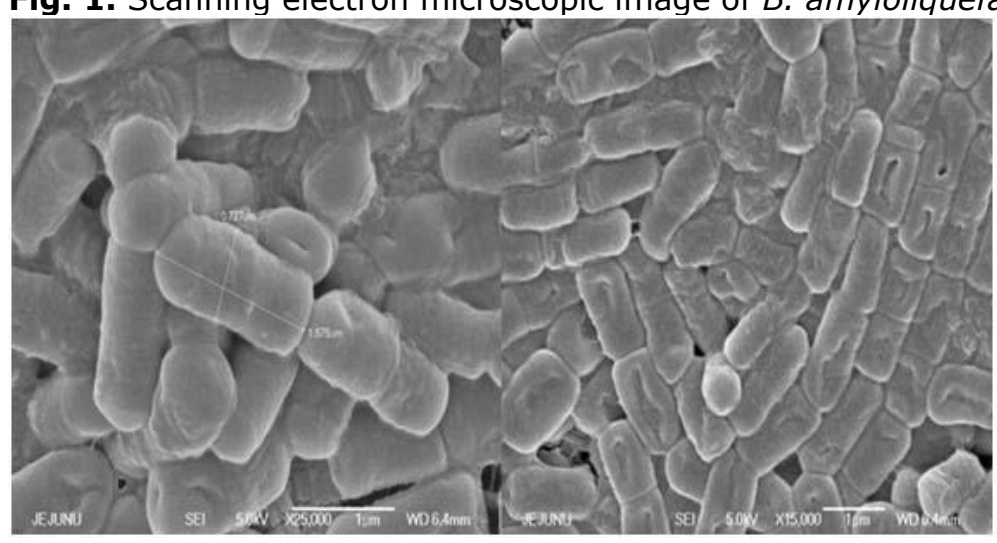


The 16S rRNA gene sequence of isolate JFP2 showed high similarities ( $>99 \%$ ) to Bacillus amyloliquefaciens and the phylogenetic tree constructed based on the 16S rRNA gene sequences confirmed this. (Fig. 2). The isolate was designated as JFP2. Except for chloramphenicol, the isolated strain JFP2 was sensitive to all the other tested antibiotics namely erythromycin, vancomycin, tetracycline, streptomycin, kanamycin, ampicillin, penicillin, neomycin, oxytetracyclin (Table 1 ).

Fig. 2. Phylogenetic tree constructed using the $16 \mathrm{~S}$ rRNA gene sequences of $B$. amyloliquefaciens JFP2.

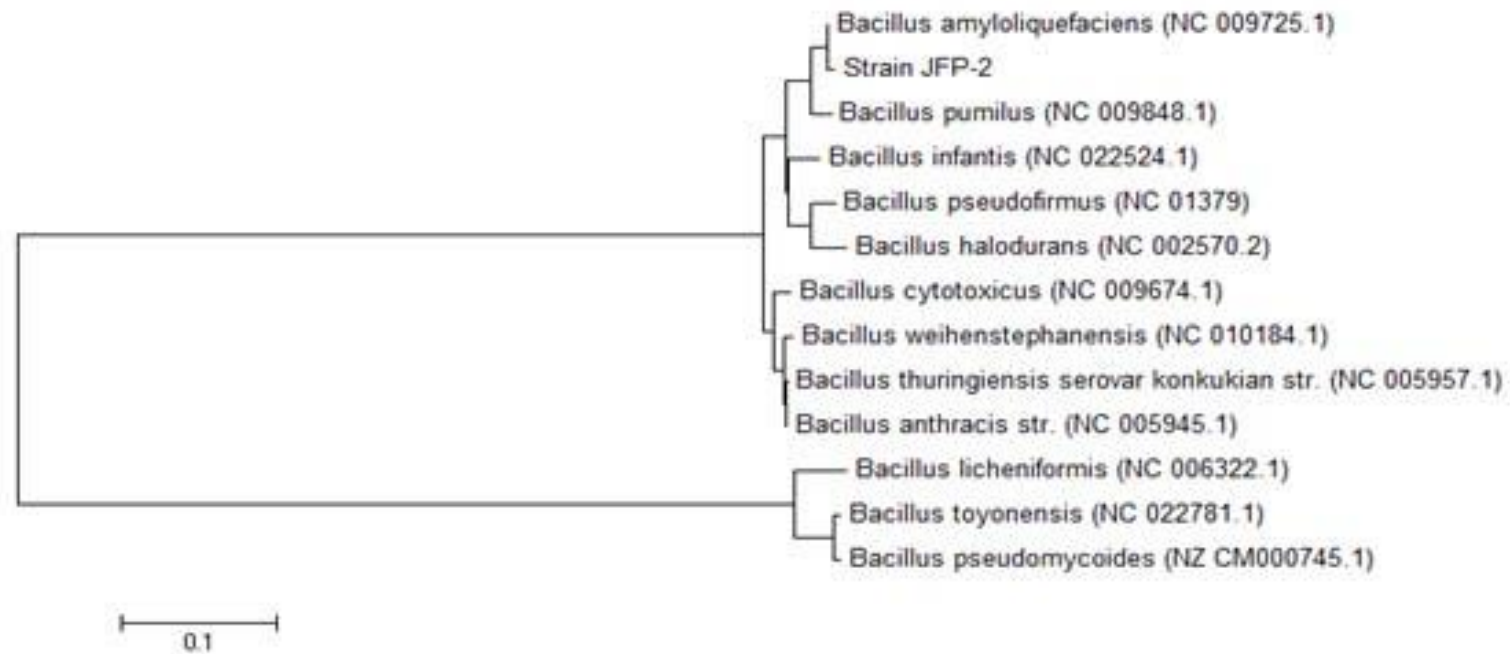

Table 1. Antibiotic resistance of $B$. amyloliquefaciens JFP2

\begin{tabular}{ll}
\hline Antibiotics $(50 \mu \mathrm{g} / \mathrm{mL})$ & $Z I(\mathrm{~mm})$ \\
\hline Streptomycin & $16 \pm 0.12$ \\
Kanamycin & $12 \pm 0.32$ \\
Erythromycin & $17 \pm 0.21$ \\
Vancomycin & $14 \pm 0.4$ \\
Ampicillin & $18 \pm 0.11$ \\
Tetracycline & $15 \pm 0.13$ \\
Penicillin & $16 \pm 0.23$ \\
Oxytetracyclin & $14 \pm 0.13$ \\
Neomycin & $15 \pm 0.11$ \\
Chloramphenicol & $3 \pm 0.1$ \\
\hline
\end{tabular}

Probiotic properties of $B$. amyloliquefaciens JFP2. Viability of the isolated JFP2 strain at low $\mathrm{pH}$ and high temperature conditions are shown in Figure 3. The result indicated that cell viability increased slightly at $\mathrm{pH} 2.0$ while at $\mathrm{pH} 3.0$ and 4.0 the strain JFP2 survived and grew. Survival ability of strain JFP2 in the presence of bile salt (Oxgall, $0.3 \%$ ) is also presented in Figure 3. Results revealed that the strain was able to grow in the presence of oxgall. 


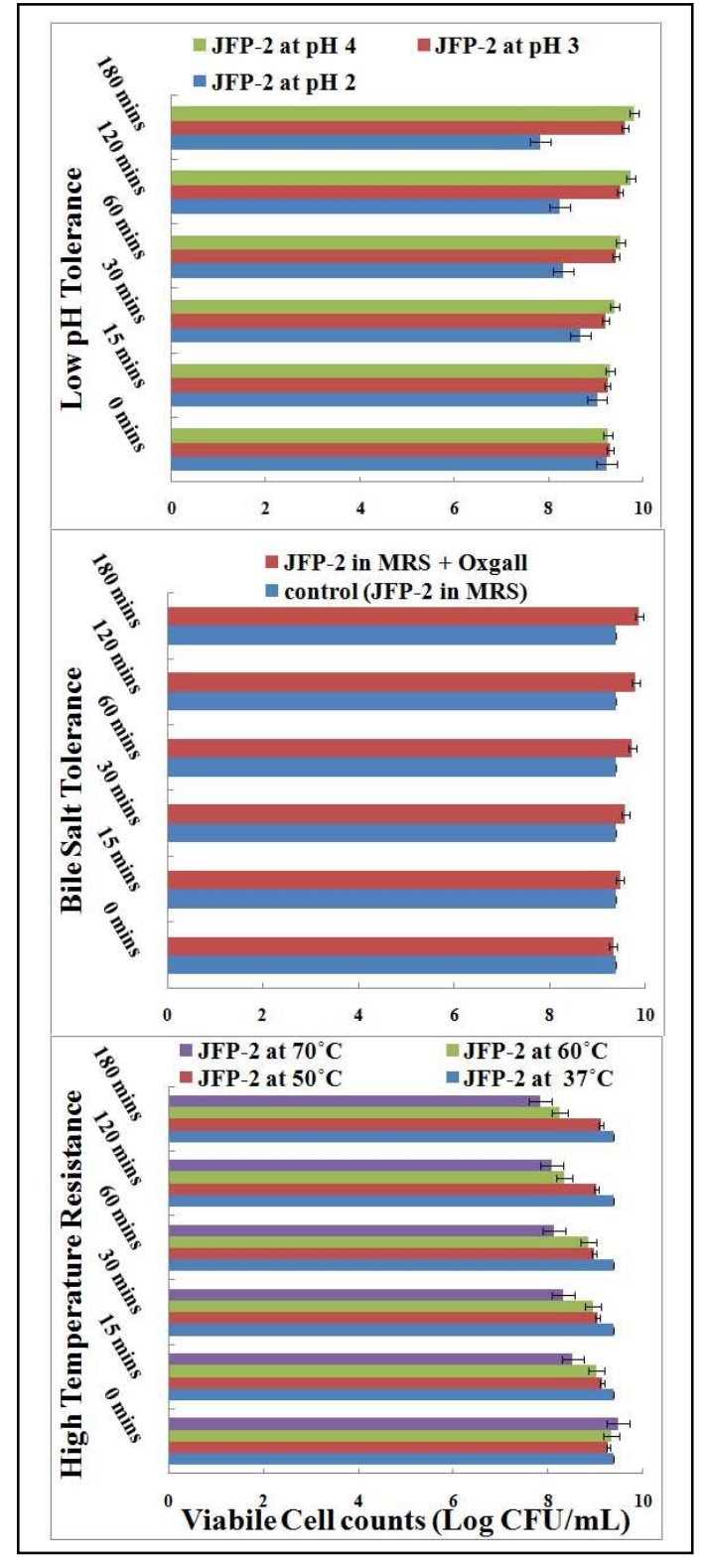

Fig. 3. Effect of low pH, high temperature and bile salts on viability of $B$. amyloliquefaciens JFP2.

Positive proteolytic activity of strain JFP2 was determined with $0.057 \mathrm{mg} / \mathrm{ml}$ tyrosine liberation. Strain JFP2 also exhibited high hydrophobicity expressed as $97.43 \%, 92.54 \%$, and $79.56 \%$, of microbial adhesion to hexadecane, toluene and xylene respectively (Fig. 4). A significant dose-dependent inhibition of DPPH activity was shown by the strain JFP2, with the highest free radical-scavenging activity $(73.5 \%)$ occurring at $6 \mathrm{ml}$ of cells $\left(10^{6} \mathrm{CFU} / \mathrm{ml}\right)$ (Fig. 5).

Fig. 4. Hydrophobicity of $B$. amyloliquefaciens JFP2 against various solvents

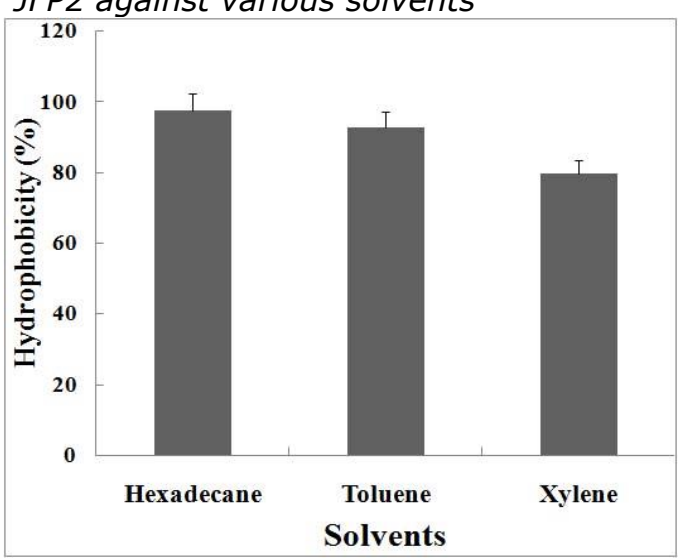

Fig.5. Antioxidant activities of $B$ amyloliquefaciens JFP2

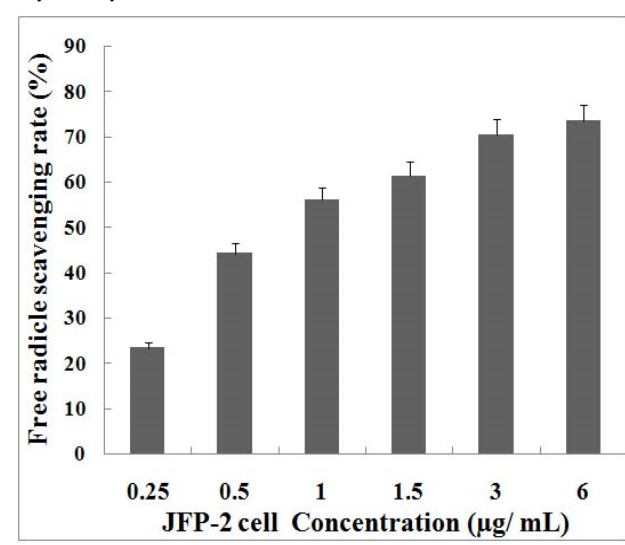

Antibacterial properties of $B$. amyloliquefaciens JFP2. Antibacterial effect of the isolated strain JFP2 against the five pathogens appears in Table 2. 
Table 2. Antimicrobial activity of bacteriocin JFP2 from B. amyloliquefaciens against seven major fish pathogens

\begin{tabular}{lll}
\hline Indicator fish pathoqens & Zone of inhibition $(\mathrm{mm})^{a}$ & Minimum inhibitoryconcentration $(\mu \mathrm{g} / \mathrm{mL})$ \\
\hline Aeromonas hydrophila & $14.4 \pm 013$ & 12.5 \\
Edwardsiella tarda & $17.2 \pm 0.35$ & 7.5 \\
Photobacterium damselase & $13.3 \pm 0.14$ & 25.0 \\
Photobacterium phosphoreum & $13.21 \pm 0.2$ & 25.0 \\
Streptococcous parauberis & $14.24 \pm 0.23$ & 12.5 \\
S. iniae & $12.92 \pm 0.11$ & 25.0 \\
Vibrio anguillarum & $12.43 \pm 0.21$ & 25.0 \\
\hline
\end{tabular}

a Antibacterial activities were monitored by growing the bacteria in $\mathrm{BHI}$ and incubated at $37^{\circ} \mathrm{C}$ for $17 \mathrm{~h}$. Among the seven pathogenic microbes, significant growth inhibition occurred against $E$. tarda with the maximum zone inhibition of $17.2 \pm 0.35 \mathrm{~mm}$ along with the MIC value of

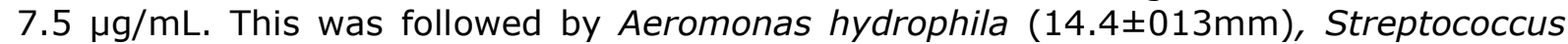
parauberis $(14.24 \pm 0.23 \mathrm{~mm})$, Photobacterium damselase $(13.32 \pm 0.14 \mathrm{~mm})$, Photobacterium phosphorem (13.21 $\pm 0.2 \mathrm{~mm}), \quad$. iniae $(12.92 \pm 0.11)$ and Vibrio anguillaram (12.43 \pm 0.21$)$. The presence of an antibacterial substance was assessed by ammonium sulfate precipitation and CM-Sephadex column purification, which was then separated by SDS-PAGE to reveal a single protein band of 37kDa (Fig. 6).

Fig. 6. SDS-PAGE of partially purified bacteriocin JFP2. Lane M - protein size marker; Lane 1 - Cell free culture supernatant; Lane 2 - purified bacteriocin JFP2.

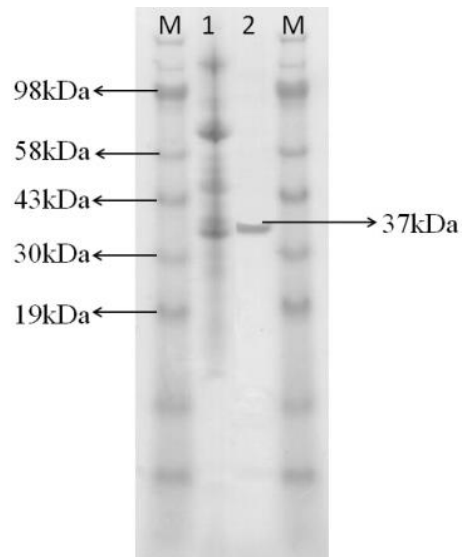

The residual antibacterial activity of $B$. amyloliquefaciens JFP2 bacteriocin after treatment with various temperature, $\mathrm{pH}$ and enzymes can be seen in Table 3.

Table 3. Effect of $\mathrm{pH}$, temperature \& enzymes on antibacterial activity of bacteriocin JFP2 against $A$. hydrophila

\begin{tabular}{ll}
\hline Treatment $^{a}$ & Residual antimicrobial activity $(\%)^{b}$ \\
\hline $\mathrm{pH}$ & 70 \\
2 & 85 \\
4 & 100 \\
6 & 100 \\
7 & 100 \\
8 & 100 \\
9 & 98 \\
10 & 95 \\
11 & 95 \\
12 & \\
Temperature (o') & 90 \\
4 & 94 \\
30 & 82 \\
& 40 \\
45 & 5 \\
60 & \\
75 & 95 \\
& 95 \\
Enzymes & 99 \\
a-Amylase & 15 \\
a-Glucosidase & 12 \\
Lipase & 10 \\
Pepsin & \\
Proteinase K & \\
Trypsin & \\
\hline
\end{tabular}

aThe final enzyme concentration was 15 $\mathrm{mg} / \mathrm{mL}$. ' ${ }^{\mathrm{b}}$ The relative residual activity was measured by the modified spot-on-lawn method, and \% activity is indicated by comparing with untreated bacteriocin JFP2 
The residual bacteriocidal activity of bacteriocin JFP2 between $4{ }^{\circ} \mathrm{C}-45^{\circ} \mathrm{C}$ exposure ranged from $94-40 \%$. Activity was only $5 \%$ at $60^{\circ} \mathrm{C}$. In the range of $\mathrm{pH} 2-12$, bactericidal activity was between $70-100 \%$. However, enzymatic degradation of bacterioncin JFP2 with proteniase $\mathrm{K}$, pepsin and trypsin showed a great loss of antimicrobial activity. This indicates the proteinaceous nature of the bacteriocin (Table 2). Cell wall degradation assay showed decreased optical density with increased degradation of $A$. hydrophila cells by bacteriocin JFP2 when incubated for 5 hours at $37^{\circ} \mathrm{C}$ (Fig. 7).

Fig. 7. Cell wall degradation of Aeromonas hydrophila by bacteriocin JFP2.

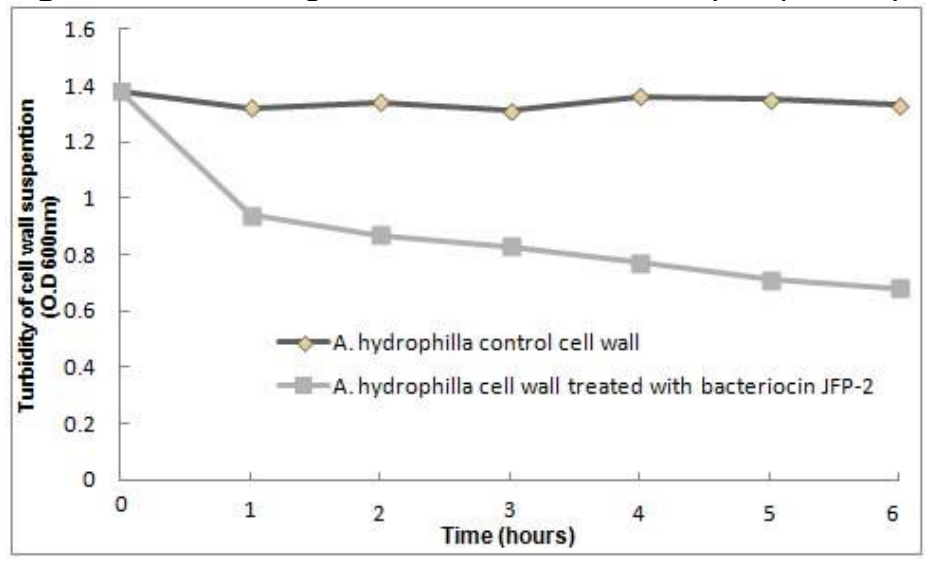

Dietary influence of $B$. amyloliquefaciens JFP2 in olive flounder. The highest live weight gain, FCR and SGR occurred with the probiotic fed fish group compared with the control (Table 4). There were no significant differences among the probiotic diet group. Fish fed $B$. amyloliquefaciens JFP2 enriched probiotic diet had higher survival rate ( $\mathrm{P} 1: 93.86 \%$ and $\mathrm{P} 2: 95.31 \%$ ) than the control diet fed fish group (64.32\%).

Table 4. Dietary influence of $B$. amyloliquefaciens JFP2 on growth and survival of flounder fish challenged with $S$. iniae.

\begin{tabular}{llll}
\hline Parameters & \multicolumn{3}{l}{ Experimental diets } \\
\cline { 2 - 4 } & \multicolumn{1}{l}{ Control } & \multicolumn{1}{l}{$P 1$} & $P 2$ \\
\hline Initial weight (g) & $105 \pm 0.26^{\mathrm{a}}$ & $104 \pm 0.11^{\mathrm{a}}$ & $106 \pm 0.02^{\mathrm{a}}$ \\
Final weight (g) & $112 \pm 0.26^{\mathrm{a}}$ & $116 \pm 0.23^{\mathrm{ab}}$ & $121 \pm 0.08^{\mathrm{b}}$ \\
LWG (\%) & $6.67 \pm 0.19^{\mathrm{a}}$ & $11.54 \pm 0.13^{\mathrm{ab}}$ & $14.15 \pm 0.21^{\mathrm{b}}$ \\
FCR (\%) & $1.14 \pm 0.14^{\mathrm{a}}$ & $1.27 \pm 0.07^{\mathrm{ab}}$ & $1.29 \pm 0.18^{\mathrm{b}}$ \\
SGR (\%) & $0.32 \pm 0.12^{\mathrm{a}}$ & $0.87 \pm 0.31^{\mathrm{b}}$ & $0.94 \pm 0.16^{\mathrm{b}}$ \\
Survival rate (\%) & $64.32 \pm 2.13^{\mathrm{a}}$ & $93.86 \pm 2.16^{\mathrm{b}}$ & $95.31 \pm 2.09^{\mathrm{b}}$ \\
\hline
\end{tabular}

Probiotic enriched feed P1=1.4 × $10^{4} \mathrm{CFU} / 100 \mathrm{~g}$ feed; $\mathrm{P} 2=1.4 \times 10^{8} \mathrm{CFU} / 100 \mathrm{~g}$ of control feed. $*$ Values (Mean \pm SD) in the same row with different superscripts are significantly different from each other $(\mathrm{P}<0.05)$; LWG\%: [final weight $(\mathrm{g})$ - initial weight $(\mathrm{g}) /$ initial weight $(\mathrm{g})$ ] $\times 100 ; \mathrm{SGR}=$ [In final body weight - In initial body weight/time (days)] $\times 100 ;$ FCR $=$ Feed consumed / Weight gain; $S R=$ [ end number of the alive fish/the beginning number of the fish] $\times 100$.

\section{Discussion}

The morphological, phylogenetic, and biochemical results suggest that JFP2 isolate is a member of the Bacillus species. Previous studies have also reported the presence of Bacillus spp. from similar fermented food products (Nam and Ahn 2015; Namgung et al., 2010). Resistance to antibiotics was strain-dependent. Previous studies have reported that $B$. subtilis, a major fermenting bacterial species of Mbuja, exhibited $18 \%-64 \%$ resistance to tetracycline and chloramphenicol while $B$. thuringiensis showed resistance to ampicillin and chloramphenicol (Mohammadou et al., 2014).

The ability of microorganisms to survive in the gastrointestinal tract is one of the main important characteristics required for probiotic bacteria. The acidic conditions $(\mathrm{pH}$ 2 ) in the stomach and the bile salt concentration in the gastrointestinal track are adverse conditions that probiotic bacteria must overcome when taken orally (Prasad et al., 1998) to allow their colonization in the intestinal surface. Growth at $\mathrm{pH} 2$ and in $0.3 \%$ oxgall suggests that Bacillus amyloliquefaciens JFP2 is able to withstand these harsh gastric 
environments. The strain $B$. amyloliquefaciens JFP2 also grew at high temperatures which could be a positive trait for commercial use. The isolate JFP2 showed a positive proteolytic activity with highly expressed hydrophobicity and significant antioxidant capacity. All these suggest that the isolated strain B. amyloliquefaciens JFP2 can be used as a potential probiotic bacteria (Arusu et al., 2014).

Bacillus amyloliquefaciens JFP2 showed a wide spectrum of antibacterial activity against the seven major fish pathogens (Table 3 ). The antibacterial activity of the strain JFP2 was not only evident against Gram-positive bacteria but also against Gram-negative ones, with maximum inhibition against $E$. tarda $(17.2 \pm 0.35 \mathrm{~mm})$. A similar antagonistic effect of bacteriocin was produced by Bacillus subtilis against common fish pathogens such as Aeromonas hydrophila, Edwardsiella tarda, Pseudomonas aeruginosa, Pseudomonas fluorescens, Flavobacterium branchiophilum (Nayak and Mukherjee, 2011). The isolated strain JFP2 showed a significant antibacterial effect and the JFP2 CFCS was subjected to Sephadex G-100 gel filtration and SDS-PAGE separation of $37 \mathrm{kDa}$ bacteriocin. These were consistent with previous reports on similar molecular weight of bacteriocin produced by B. amyloliquefaciens J4, $39 \mathrm{kDa}$ (Lim et al., 2011) and Bacillus sp. SW1, $38 \mathrm{kDa}$ (Kim et al., 2014), and higher than the other bacteriocin produced by $B$. subtilis YS-1005, $27 \mathrm{kDa}$ (Kim et al., 1999), and B. subtilis YU-1432, $29 \mathrm{kDa}$ (Lee and Lee, 2011). Additionally, bacteriocin JFP2 residual activity was similar to other bacteriocins produced by L. lactis ssp. Diacetilactis (Kojic et al., 1991) but in contrast, Lactacin $\mathrm{F}$, after exposure at $50^{\circ} \mathrm{C}$ for $30 \mathrm{~min}$, no activity was identified (Kim et al., 2005). After exposure to proteniase $K$ there was loss of activity and pepsin and trypsin confirmed their proteinaceous nature which was concurrent with previous studies (Nilsen et al., 2003; Nam and Ahn, 2015).

Antibacterial mechanisms of bacteriocins are broadly divided into three types: bacteriostatic, bactericidal, and bacteriolytic (Cotter et al., 2013). In the present study, the mechanism of bacteriocin JFP2 was determined the cell wall degradation method. The bacteriocin JFP2 was treated with cell walls of $A$. hydrophila for 5 hours at $37^{\circ} \mathrm{C}$. The optical density was decreased with increased cell wall degradation by the bacteriocin JFP2 (Fig. 7). Our results showed a bacteriolytic mode of the antibacterial mechanism of bacteriocin JFP2 isolated from the Jeju Island's traditional fermented food against $A$. hydrophila. The bacteriocin protein that kills other bacterial cells through cell wall degradation are class III bacteriocins (Bastos et al., 2010). The isolated strain $B$. amyloliquefaceins JFP2 also produces a large $37 \mathrm{kDa}$, heat stable antibacterial protein and because of its cell wall degradation mode it can be classified as class IIIa bacteriocin molecule. However, bacteriocin JFP2 need further studies to confirm its classifications.

The results of the present study showed that Jeju Island's traditional fermented sea food Jeotgal harbors probiotic bacteria such as $B$. amyloliquefaciens which produce bacteriocin JFP2. This can be used as a potential antibacterial agent against fish pathogenic bacteria. Recently, in-vitro antibacterial, antifungal and antioxidant properties of $B$. amyloliquefaciens isolated from soil sludge have proved that the $B$. amyloliquefaciens could be potent as probiotic bacteria (Kadaikunnan et al., 2105). Moreover, flounder juveniles fed with B. amyloliquefaciens-JFP2 enriched feed can overcome S. iniae infection. A detailed biochemical and immunological study on the dietary effect of this potential bacterium is currently being carried out (data not shown). Based on our results we believe that $B$. amyloliquefaciens JFP2 and/or its bacteriocin can be used as a bio-control agent of pathogenic bacteria if supplemented by feed industries in aquaculture feeds.

\section{Acknowledgements}

The authors are grateful to the National Research Foundation of Korea (NRF) grants funded by the Korea government (MEST) (No.2016H1D5A1911152). 


\section{References}

Arusu M.V., Jung M-W., Kim D.H., Ilavenil S., Jane M., Park H.S., et al., 2014. Enhancing nutritional quality of silage by fermentation with Lactobacillus plantarum. Ind J Microbiol. 54: 396-402.

Avonts L. and L. De Vuyst, 2001. Antimicrobial potential of probiotic lactic acid bacteria. Meded. Rijksuniv. Gent. Fak. Landbouwkd. Toegep. Biol. Wet. 66: 543-550.

Bansemir A., Maja B., Susanne S. and L. Ulrike, 2006. Screening of cultivated seaweeds for antibacterial activity against fish pathogenic bacteria. Aquarculture, 252: 79-84.

Bastos M.C.F., Coutinho B.G. and M.L.V. Coelho, 2010. Lysostaphin: A Staphylococcal bacteriolysin with potential clinical applications. Pharmaceuticals. 3: 1139-1161.

Borrero J., Brede D.A., Skaugen M., Diep D.B., Herranz C., Nes I.F., Cintas L.M. and P.E. Hemández, 2011. Characterization of garvicin ML, a novel circular bacteriocin produced by Lactococcus garvieae DCC43, isolated from mallard ducks (Anas platyrhynchos). Appl. Environ. Microbiol. 77: 369-373.

Choi E.J., Lee S.H., Jung J.Y. and C.O. Jeon, 2013. Brevibacterium jeotgali sp. nov., isolated from jeotgal, a traditional Korean fermented seafood. Int. J. Syst. Evol. Microbiol. 63: 3430-3436.

Citi J.E., Sandime W.E. and P.R. Eliker, 1963. Some observation on the Hull method for measurement of proteolysis in milk. J. Dairy Sci. 46: 337-45.

Cleveland J., Montville T.J., Nes I.F. and M.L. Chikindas, 2001. Bacteriocins: safe, natural antimicrobials for food preservation. Int. J. Food Microbiol. 71: 1-20.

Collins B., Cotter P.D., Hill C. and R.P. Ross, 2010. Applications of lactic acid bacteria produced bacteriocins, pp. 89-109. In Mozzi F, Raya RR, Vignolo GM. (eds.), Biotechnology of lactic acid bacteria: Novel applications. Wiley-Blackwell.

Cotter P.D., Ross R.P. and C. Hill, 2013. Bacteriocins-a viable alternative to antibiotics? Nat. Rev. Microbiol. 11: 95-105.

Ganguly S., Paul I. and S.K. Mukhopadhayay, 2010. Application and effectiveness of immunostimulants, probiotics, and prebiotics in aquaculture: A review. Isr. J. Aquacult.Bamidgeh, 60:130-138.

Guan L., Cho K.H. and J.H. Lee, 2011. Analysis of the cultivable bacterial community in jeotgal, a Korean salted and fermented seafood, and identification of its dominant bacteria. Food Microbiol. 28: 101-113.

Kadaikunnan S., Rejiniemon T.S., Khaled J.M., Alharbi N.S. and R. Mothana, 2015. In-vitro antibacterial, antifungal, antioxidant and functional properties of Bacillus amyloliquefaciens. Ann. Clin. Microbiol. Antimicrob. 14: 9.

Kim M.H., Kong Y.J., Baek H. and H.H. Hyun, 2005. Production, purification and characterization of micrococcin GO5, a bacteriocin produced by Micrococcus sp. GO5 isolated from Kimchi. J. Food Prot. 68: 157-163.

Kim S.O., Ohk S.H., Bai D.H. and J.H. Yu, 1999. Purification and properties of bacteriolytic enzymes from Bacillus licheniformis YS-1005 against Streptococcus mutans. Biosci. Biotechnol. Biochem. 63: 73-77.

Kim Y.O., Park I.S., Kim D.J., Nam B.H., Kim D.G., Jee Y.J. and C.M. An, 2014. Identification and characterization of a bacteriocin produced by an isolated Bacillus sp. SW1-1 tha exhibits antibacterial activity against fish pathogens. J. Korean Soc. Appl. Biol. Chem. 57(5): $605-612$.

Kojic M., Svircevic J., Banina A. and L. Topisirovic, 1991. Bacteriocin producing strain of Lactococcus lactis subsp. diacitilactis S50. Appl. Environ. Microbiol. 57: 18351837.

Lee C.H., 1993. Fish fermentation technology, pp. 189-279. In Lee $\mathrm{CH}$, Steinkraus $\mathrm{KH}$, Reilly PJA (eds), Fish fermentation technology in Korea. United Nations University Press, Tokyo.

Lee H.S. and H.J. Lee, 2011. Purification and biochemical characterization of bacteriolytic enzyme from Bacillus subtilis YU-1432 active against Porphyromonas gingivalis. J. Korean Soc. Appl. Biol. Chem. 54: 600-605.

Lee H., Yoon H., Ji Y., Kim H., Park H., Lee J., et al., 2011. Functional properties of Lactobacillus strains isolated from kimchi. Int. J. Food Microbiol. 145: 155-161. 
Lee S.H., Jung J.Y. and C.O. Jeon, 2014. Effects of temperature on microbial succession and metabolite change during saeu-jeot fermentation. Food Microbiol. 38: 1625.

Li S., Zhao Y., Zhang L., Zhang X., Huang L., Li D., et al., 2012 Antioxidant activity of Lactobacillus plantarum strains isolated from traditional Chinese fermented foods. Food Chem. 135: 1914-1919.

Lim J.H., Jeong H.Y. and S,D. Kim, 2011. Characterization of the bacteriocin J4 produced by Bacillus amyloliquefaciens $\mathrm{J} 4$ isolated from Korean traditional fermented soybean paste. J. Korean Soc. Appl. Biol.Chem. 54: 468-474.

Mohammadou, B.A., Le Blay G., Mbofung C.M. and G. Barbier, 2014. Antimicrobial activities, toxinogenic potential and sensitivity to antibiotics of Bacillus strains isolated from Mbuja, an Hibiscus sabdariffa fermented seeds from Cameroon. African J. Biotechnol. 13: 3617-3627.

Nam E.S. and J.S. Ahn, 2015. A Lactic acid bacterium isolated from Korean fermented fish, Jeotgal: Characterization of Weissella halotolerans KNOUC4036 as a probiotic. Int. J. Adv. Res. Biol.Sci. 2: 9-19.

Namgung H.J., Park H.J., Cho I.H., Choi H.K., Kwon D.Y., Shim S.M. and Y.S. Kim, 2010. Metabolite profiling of doenjang, fermented soybean paste during fermentation. J. Sci. Food Agric. 90: 1926-1935.

Nayak S.K. and S.C. Mukherjee, 2011. Partial Purification and Characterization of the Inhibitory Substance of Bacillus subtilis against Common Bacterial Fish Pathogens. Isr. J. Aquacult. - Bamidgeh, 648, 5 pages.

Nilsen T., Nes I.F. and H. Holo, 2003. Enterolysin A, a cell wall degrading bacteriocin from Enterococcus faecalis LMG 2333. Appl. Environ. Microbiol. 69: 2975-2984.

Paik H.D. and B.A. Glatz, 1995. Purification and partial amino acid sequence of propionicin PLG-1, a bacteriocin produced by Propioni bacterium thoenii P127. Lait 75: 367-377.

Prasad J., Gill H.S., Smart J.B. and P.K. Gopal, 1998. Selection and characterization of Lactobacillus and Bifidobacterium strains for use as probiotics. Int. Dairy J. 8: 9931002.

Roh S.W., Kim K.H., Nam Y.D., Chang H.W., Park E.J. and J.W. Bae, 2010. Investigation of archaeal and bacterial diversity in fermented seafood using barcoded pyrosequencing. ISME J. 4: 1-16.

Shen P., Fan X.R. and G.W. Li, 1999. Experiment of Microbiology. Beijing: Higher Education Press.

Walker D.R. and S.E. Gilliland, 1993. Relationship among bile tolerance, bile salt deconjugation, and assimilation of cholesterol by Lactobacullus acidophilus. J. Dairy Sci. 76: $956-961$.

Wayne. 1997. National Committee for Clinical Laboratory Standards. Performance standards for antimicrobial disk susceptibility tests. Approved standard M2-A6. Wayne, Pa: National Committee for Clinical Laboratory Standards. 